\title{
Spectrophotometric study of the interaction between arsenic and bovine serum albumin
}

\author{
This article was published in the following Dove Press journal: \\ Research and Reports in Biology \\ II August 2015 \\ Number of times this article has been viewed
}

\section{Rolando A Curvale' \\ Nora B Debattista' \\ Nora B Pappano' \\ Diana M Gonzalez ${ }^{2}$ \\ Daniela A Curvale²}

'Area of Physical Chemistry, ${ }^{2}$ Area of Pharmacology and Toxicology, Chemistry, Biochemistry and

Pharmacy Faculty, San Luis National University, San Luis, Argentina
Correspondence: Rolando A Curvale San Luis National University, Andes Army 950, D 5700HHW

San Luis, Argentina

Tel +54 2664520300

Email rcurvale@unsl.edu.ar
Abstract: Argentina is one of the countries that are most widely affected by chronic endemic regional hydroarsenicism, a syndrome caused by the constant consumption of water polluted with arsenic at higher levels. In this study, the interaction of bovine serum albumin with arsenite and arsenate was analyzed employing UV-Vis spectroscopy, considering its low cost and greater availability. The number of binding sites, binding constants, and thermodynamic parameters $\Delta G^{\circ}, \Delta H^{\circ}$, and $\Delta S^{\circ}$-were determined. The results obtained indicate that the interaction of bovine serum albumin with arsenate is ionic, while that with arsenite is hydrophobic.

Keywords: arsenic, bovine serum albumin, UV spectroscopy, thermodynamic parameters

\section{Introduction}

Arsenic is a natural element that is widely distributed in the atmosphere, hydrosphere, and biosphere. Although a huge amount of arsenic in the environment comes from natural sources (weathering, biological activity, volcanic emissions), human activity is greatly responsible for its production, whether by industrial processes (mining, smelting of metals, wood preservatives, and so on) ${ }^{1}$ or by agricultural activities (insecticides, fungicides, and herbicides). ${ }^{2}$ Arsenic can be present in different oxidation states (-III, 0 , III, V), in organic and inorganic forms, and in a wide range of concentrations in the air, water, the soil, vegetables, and animals. Arsenic compounds can cause lung, bladder, or skin cancer; ${ }^{3,4}$ or different diseases such as hepatic diseases, renal diseases, ${ }^{5}$ neurological diseases, ${ }^{6}$ hematologic and circulatory disorders; and can even cause death. ${ }^{7,8}$ These compounds are considered protoplasmic toxins that act mainly by suppressing the enzymatic systems. ${ }^{9}$ The World Health Organization (WHO) estimates that 1 out of 10,000 inhabitants runs the risk of contracting skin cancer due to the ingestion of water contaminated with arsenic. ${ }^{10}$ Argentina is one of the countries that are most widely affected by chronic endemic regional hydroarsenicism, a syndrome caused by the constant consumption of water polluted with arsenic at higher levels than those set by WHO. The underground water aquifers of the Argentine central provinces, including San Luis, are polluted with arsenic. In most cases, the causes are natural and are related to volcanic activity and to the hydrothermal activity associated with the Andes. ${ }^{11,12}$

The different forms of arsenic show different levels of toxicity; inorganic arsenite (iAs $\left.{ }^{I I I}\right)$, the most toxic inorganic form, is ten times more toxic than inorganic arsenate $(i A s \mathrm{v})$. The levels of arsenic (As) in the environment vary since it is an element with high mobility and transformation capacity. Organic forms of As often appear in lower 
concentrations than inorganic forms, although the level of organic forms increases as a result of methylation reactions produced by microbial activity. ${ }^{13} \mathrm{iAs}^{\mathrm{V}}$ is the most widely found species of arsenic in the environment, the majority of which is found in water and the soil. The toxicity of As can be related to the degradation of proteins or to the limitation of the synthesis of methylated metabolites that contain $\mathrm{As}^{\mathrm{III}}$. Methylation of iAs ${ }^{\mathrm{III}}$ to monomethyl arsenic or dimethyl arsenic is a biotransformation mechanism that is preceded by reduction of $\mathrm{iAs}^{\mathrm{V}}$ to $\mathrm{iAs} \mathrm{s}^{\mathrm{III}}$ and subsequent methylation. The binding of $\mathrm{iAs}^{\mathrm{III}}$ to proteins could be the first stage of the biotransformation mechanism. ${ }^{14}$ Arsenic forms covalent bonds with the sulfur atom of the sulfhydryl or thiol groups only when water is present. ${ }^{15,16} \mathrm{iAs}^{\mathrm{III}}$ enters the pyruvateoxidase system, binding to the sulfhydryl groups of proteins, and forms a very stable ring complex.

The most relevant property of mammal serum albumin is its ability to reversibly bind to a large variety of endogenous and exogenous ligands, acting as a nonspecific carrier. ${ }^{17}$ The majority of albumins contain 17 disulfide bridges and a thiol group that is a free cysteine (Cys). This residue (Cys 34) is reactive, polarizable, and redox-active; it has a high affinity for metals and is especially sensitive to the local environment; ${ }^{18,19}$ its functionality is accompanied by the Tyr 84 residue. ${ }^{20}$ Reactive oxygen species can increase the oxidization state of the sulfur atom in Cys, generating sulfenic, sulfinic, and sulfonic oxacids. This characteristic suggests that redox reactions are used to efficiently biotransform reactive species or to fulfill the role of regulating metabolic pathways. Proteins possess other residues that contain sulfur, such as methionine, but the Cys residues are the most sensitive ones to redox processes. The formation of the disulfide bridge stabilizes extracellular proteins, protects against inactivation, determines the association with other proteins, and regulates its functions. ${ }^{21}$ When bovine serum albumin (BSA), structurally similar to human serum albumin (HSA), was employed to investigate its possible binding sites to As using displacement markers, it was found to bind to specific Sudlow's sites I and II of BSA.22

Considering that arsenic has a tendency to form strong bonds with proteins ${ }^{23}$ and that inhabitants of rural towns run a greater risk of arsenic consumption through contaminated water, this study set out to determine the number of sites, the intrinsic constant of the As-BSA bond, and the thermodynamic parameters of this association by way of employing a spectrophotometric technique. BSA was used instead of HSA owing to its low cost and greater availability.

\section{Materials and method Materials}

Lyophilized BSA powder with a degree of purity greater than $98 \%$ (molecular weight, $66,500 \mathrm{~g} / \mathrm{mol}$ ) was provided by FEDESA-UNSL (Cordoba, Argentina). Solutions of $6.67 \times 10^{-4} \mathrm{M}$ were prepared with $\mathrm{Na}_{2} \mathrm{HAsO}_{4} \cdot 7 \mathrm{H}_{2} \mathrm{O}\left[\mathrm{iAs}{ }^{\mathrm{V}}\right]$ (Mallinckrodt Plc, Dublin, Ireland) and $7.0 \times 10^{-4} \mathrm{M}$ with $\mathrm{NaAsO}_{2}\left[\mathrm{iAs}^{\mathrm{II}}\right]$ (BDH, Mumbai, India). Cystine and Cys hydrochloride (Tetrahedron, Baltimore, MD, USA), $\mathrm{Na}_{2} \mathrm{HPO}_{4} \cdot 12 \mathrm{H}_{2} \mathrm{O}$ and $\mathrm{NaH}_{2} \mathrm{PO}_{4} \cdot \mathrm{H}_{2} \mathrm{O}$ (Mallinckrodt), $\mathrm{KCl}$ (Merck and Co, Inc., Whitehouse Station, NJ, USA), and distilled decarbonated water were used.

\section{Instrument}

To measure the absorption, a spectrophotometer Shimadzu UV-160A (Shimadzu Corporation, Kyoto, Japan) was used, and the temperature was regulated with a thermostatic bath, RA Lauda (Lauda-Königshofen, Germany).

\section{Methodology}

A phosphate buffer solution of $0.02 \mathrm{M}, \mathrm{pH} 7.4$, and ionic strength $0.15 \mathrm{M}$ was used. The concentrations of the BSA solutions were established by weight. Approximately $2 \mathrm{~mL}$ of BSA solution was loaded into the spectrophotometer cuvette, and subsequently, $25 \mu \mathrm{L}$ of $\mathrm{AAs}^{\mathrm{V}}$ or iAs ${ }^{\mathrm{III}}$ was gradually added. Absorbances were recorded at wavelengths of 253, 278, and $280 \mathrm{~nm}$ and at three different temperatures: $20^{\circ} \mathrm{C}, 25^{\circ} \mathrm{C}$, and $37^{\circ} \mathrm{C}$. The extinction coefficients of BSA were determined from the initial absorbance value of each round of the experiment for each temperature and selected wavelength. The experiment was carried out in duplicate.

This methodology was adopted because the variation in absorbency of the complexes that form is small, as shown in Figure 1.

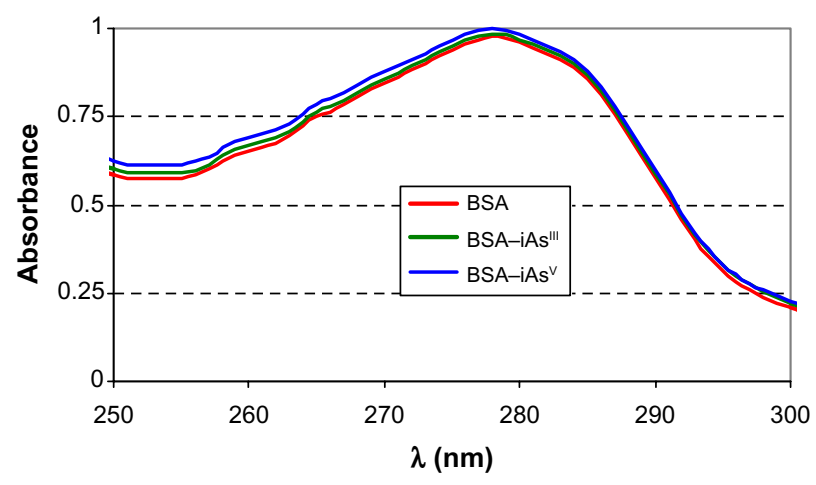

Figure I Spectral curves of BSA $\left(2.13 \times 10^{-4} \mathrm{mEq}\right), \mathrm{BSA}-\mathrm{iAs} \mathrm{s}^{\prime \prime \prime}\left(\mathrm{iAs} \mathrm{s}^{\prime \prime \prime}=1.75 \times 10^{-4} \mathrm{meq}\right)$, and $B S A-i A s^{v}\left(i A s^{\vee}=1.67 \times 10^{-4} \mathrm{meq}\right)$.

Abbreviation: BSA, bovine serum albumin. 


\section{Results and discussion}

The sodium arsenate solutions do not absorb radiation in the range of selected wavelengths. At $\mathrm{pH} \mathrm{7.4,} \mathrm{the} \mathrm{HAs}_{4}^{2-}$ species predominates over $\mathrm{H}_{2} \mathrm{As}_{4}^{1-}$. The same happens with arsenite solutions that, at this $\mathrm{pH}$, exist as $\mathrm{H}_{3} \mathrm{AsO}_{3}$, a weak acid. ${ }^{24}$ Figure 1 shows the absorption spectrum of $\mathrm{BSA}, \mathrm{BSA}-\mathrm{iAs} \mathrm{v}^{\mathrm{V}}$, and $\mathrm{BSA}-\mathrm{iAs}{ }^{\mathrm{III}}$ complexes registered in the region of $250-300 \mathrm{~nm}$.

The wavelengths of 280 and $278 \mathrm{~nm}$ were selected to observe changes in the environment of tyrosines and tryptophans and that of $253 \mathrm{~nm}$ for the possible binding to Cys.

Figure 2 shows the graph obtained with the methodology adopted from the registered absorbance values $(253 \mathrm{~nm})$ after the addition of $\mathrm{iAs}^{\mathrm{V}}$, and Figure 3 is similar to $\mathrm{iAs}{ }^{\mathrm{III}}$ instead.

\section{Considerations on the equilibrium}

In this study, the variation of absorbance between BSA and the complex was used to follow the binding process of arsenic (V or III). The relationship between the concentration of ligand $L$ and the macromolecule $P$ is termed the degree of saturation $(v)$, and represents the average number of moles of bound ligand per mole of macromolecule:

$$
v=\frac{[L]_{\text {bound }}}{[P]_{\text {total }}}
$$

Equation 2, approximation due to Klotz et al, ${ }^{25}$ relates the degree of saturation with the binding constant $K$ :

$$
\frac{1}{v}=\frac{1}{n}+\frac{1}{n K} \frac{1}{[L]}
$$

where $n$ is the number of binding sites of the macromolecule.

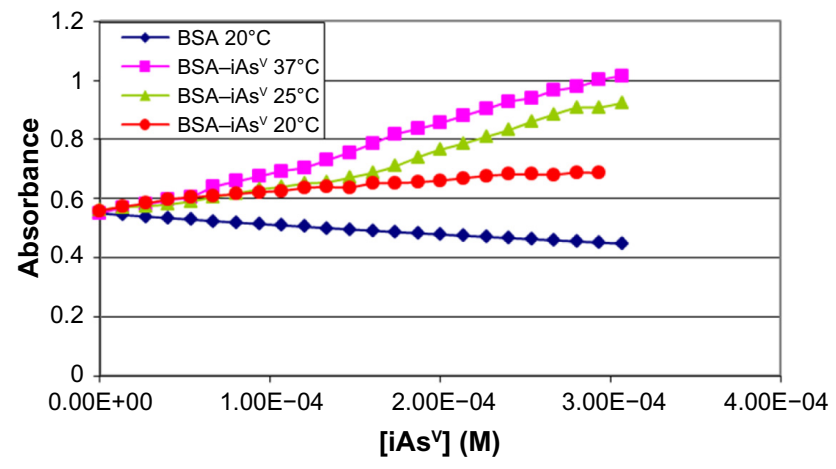

Figure 2 Absorbance of complex BSA-iAs ${ }^{\vee}$ at $253 \mathrm{~nm}$.

Notes: BSA $1.81 \times 10^{-5} \mathrm{M}$ and different concentrations of iAs ${ }^{v} .--$ it corresponds to BSA dilutions.

Abbreviation: BSA, bovine serum albumin.

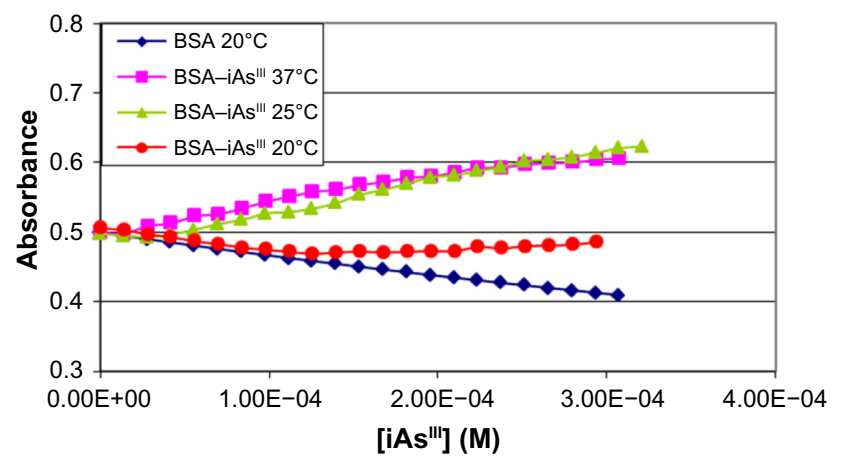

Figure 3 Absorbance of complex BSA-iAs ${ }^{\prime \prime \prime}$ at $253 \mathrm{~nm}$.

Notes: BSA I.8I $\times 10^{-5} \mathrm{M}$ and different concentrations of iAs'"I. -- it corresponds to BSA dilutions.

Abbreviation: BSA, bovine serum albumin.

From Figure 4, the obtained graph, the binding constants $K$ were determined as well as the number of binding sites $n$ between BSA and $\mathrm{iAs}^{\mathrm{V}}$ at the different temperatures. The same procedure was applied for the interaction between BSA and iAs ${ }^{I I I}$. These values are denoted in Tables 1 and 2, respectively.

The thermodynamic parameters were evaluated keeping in mind that the binding constant can be related to the change in Gibbs free energy $\left(\Delta G^{\circ}\right)$ :

$$
\Delta G^{\circ}=-R T \ln K
$$

Equation 4, from van't Hoff, relates the variation in the binding constant with the temperature and the standard enthalpy $\left(\Delta H^{\circ}\right)$, which was considered constant for both systems due to the small range of work temperatures:

$$
\ln K=-\frac{\Delta H^{\circ}}{R T}+\frac{\Delta S^{\circ}}{R}
$$

A plot of Equation 4 is shown in Figure 5.

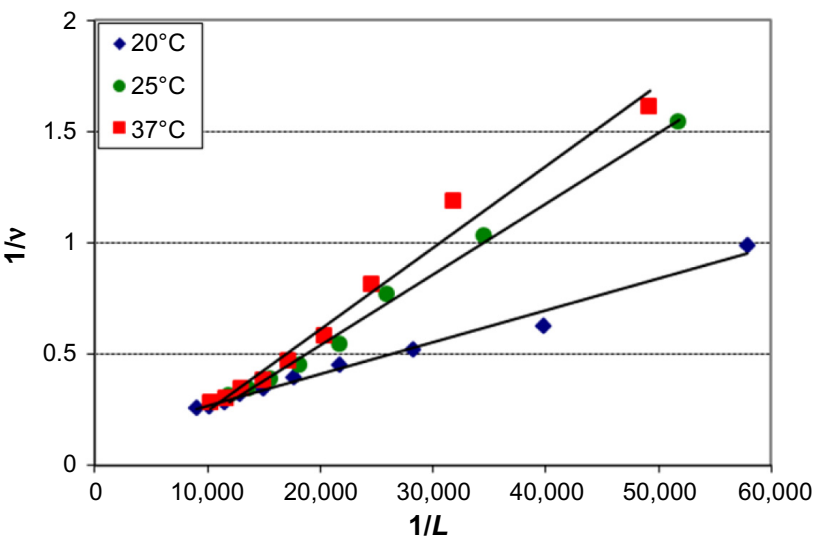

Figure 4 Graphical representation of Equation 2 (Klotz model) applied to the BSA-iAs ${ }^{\vee}$ system.

Abbreviations: $L$, concentration of ligand; $v$, degree of saturation. 
Table I Interaction between BSA and $\mathrm{iAs}{ }^{\vee}$

\begin{tabular}{llllll}
\hline $\boldsymbol{T}(\mathrm{K})$ & $\mathbf{n}$ & $\boldsymbol{K} \times 10^{-5}$ & $\Delta \boldsymbol{G}^{\circ}(\mathrm{cal} / \mathrm{mol})$ & $\Delta \boldsymbol{H}^{\circ}(\mathrm{cal} / \mathrm{mol})$ & $\Delta \boldsymbol{S}^{\circ}(\mathrm{eu})$ \\
\hline 293 & 6.9 & 6.8 & $-7,819$ & & 5.4 \\
298 & 7.6 & 3.8 & $-7,580$ & $-6,322$ & 4.2 \\
310 & 10 & 3.4 & $-7,826$ & & 4.8
\end{tabular}

Abbreviations: $T$, temperature; $n$, number of binding sites; $K$, binding constant; $\Delta G^{\circ}$, Gibbs free energy; $\Delta H^{\circ}$, standard enthalpy; $\Delta S^{\circ}$, standard entropy; BSA, bovine serum albumin.

Finally, the variation of standard entropy $\left(\Delta S^{\circ}\right)$ is given by the equation:

$$
\Delta G^{\circ}=\Delta H^{\circ}-T \Delta S^{\circ}
$$

In Tables 1 and 2, the values obtained in the interaction of BSA with iAs ${ }^{\mathrm{V}}$ (Table 1) and $\mathrm{iAs}^{\mathrm{III}}$ (Table 2) are shown.

In a solution, the protein surface is clothed by layers of water molecules, some of which are strongly perturbed by the protein through hydrogen bonding or hydrophobic interactions.

The negative values of $\Delta G^{\circ}$ indicate that the complexation reaction between $\mathrm{BSA}$ and $i \mathrm{As}^{\mathrm{V}}$ is favored; the low-enthalpy value (negative) and the entropy change (positive) suggest that the interaction is ionic (or that of charge neutralization). ${ }^{26}$

In the association between $\mathrm{iAs}{ }^{\mathrm{III}}$ and BSA, allowed by the $\Delta G^{\circ}$, the value of positive enthalpy would indicate that the process is due to the penetration of the species $\mathrm{iAs}^{\mathrm{III}}$ in the hydration surface of $\mathrm{BSA}^{27,28}$ and that the species is associated hydrophobically. This new structure is more ordered in the nonpolar sectors. The interaction is hydrophobic. ${ }^{26}$

The rise in absorbance of the $\mathrm{BSA}-\mathrm{iAs}^{\mathrm{V}}$ complex is significantly greater than that of the BSA-iAs ${ }^{\mathrm{III}}$ complex and suggests that the ionic association facilitates the molar absorptivity of chromophores groups, while the hydrophobic interaction could exert a screening effect on the radiation.

A complementary absorbance test in the region of 220-320 nm of Cys and cystine with iAs ${ }^{\mathrm{V}}$ and $\mathrm{iAs} \mathrm{s}^{\mathrm{III}}$, in a 1:1 mole relation and with a buffer solution of $\mathrm{pH} 7.4$, was carried out. It was observed that the form and magnitude of the absorption spectrum of Cys and cystine is not modified by the presence of the $\mathrm{iAs}^{\mathrm{V}}$ species, while the iAs ${ }^{\mathrm{III}}$ species interacts with cystine and

Table 2 Interaction between BSA and iAs ${ }^{\prime \prime \prime}$

\begin{tabular}{llllll}
\hline $\boldsymbol{T ( K )}$ & $\boldsymbol{n}$ & $\boldsymbol{K} \times 10^{-5}$ & $\Delta \boldsymbol{G}^{\circ}(\mathrm{cal} / \mathrm{mol})$ & $\Delta H^{\circ}(\mathrm{cal} / \mathrm{mol})$ & $\Delta S^{\circ}(\mathrm{eu})$ \\
\hline 293 & 0.6 & 1.2 & $-5,453$ & & 122.8 \\
298 & 2.5 & 6.3 & $-6,520$ & 30,524 & 124.3 \\
310 & 2.6 & 25.8 & $-7,648$ & & 123.1 \\
\hline
\end{tabular}

Abbreviations: $T$, temperature; $n$, number of binding sites; $K$, binding constant; $\Delta G^{\circ}$, Gibbs free energy; $\Delta H^{\circ}$, standard enthalpy; $\Delta S^{\circ}$, standard entropy; BSA, bovine serum albumin.

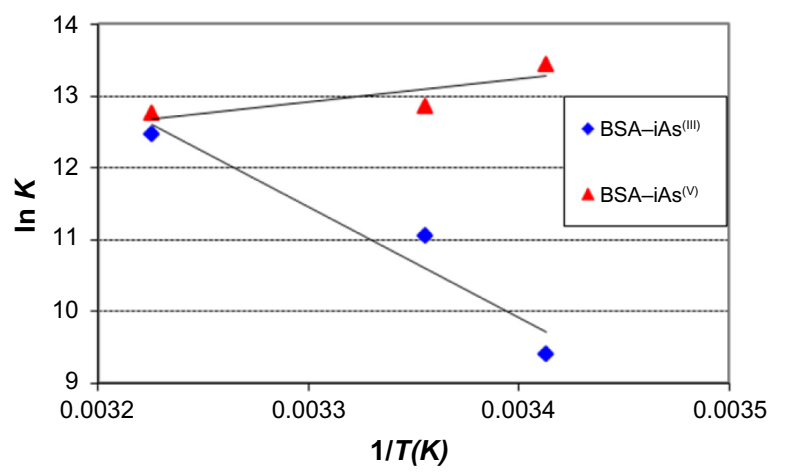

Figure 5 Graphic representation of van't Hoff equation for BSA-iAs ${ }^{\vee}$ and BSA-iAs $s^{\prime \prime \prime}$ complexes.

Abbreviations: $T$, temperature; $n$, number of binding sites; $K$, binding constant.

gives a spectrum of the same form but of greater absorbance that points to the formation of a complex. The Cys spectrum, in the presence of $\mathrm{iAs}{ }^{\mathrm{III}}$, shows a gradual rise in absorbance, from 300 to $260 \mathrm{~nm}$, and is very pronounced from 260 to 230 $\mathrm{nm}$, indicating the formation of a complex.

BSA absorbance and its complexes at 253, 278, and $280 \mathrm{~nm}$ are due to the presence of Cys, tryptophan, and tyrosine. A change in the electronic environment, greater exposition to the solvent, or a reaction of these residues modifies the absorbance. A smaller increase in absorbance in the latter wavelengths in relation to the absorbance at $253 \mathrm{~nm}$ was registered. This would indicate that tyrosine and tryptophan residues will not be responsible for complex formation, ${ }^{29}$ though the scope of this study does not allow us to confirm this.

In the interaction of BSA with $\mathrm{iAs}{ }^{\mathrm{III}}$ and $\mathrm{iAs}^{\mathrm{V}}$, a significant difference in absorbance is not observed at $253 \mathrm{~nm}$. Cys 34 has not interacted with iAs III, as expected, suggesting that this amino acid would be very protected and inaccessible.

\section{Conclusion}

Bearing in mind that the BSA molecule is hydrated, the first stage of the interaction is necessarily hydrophobic. ${ }^{30}$ The second step, of BSA association, includes ionic interactions, hydrogen bonds, and hydrophobic interactions. Considering that $\mathrm{iAs}^{\mathrm{V}}$ provides ionic ligands, while iAs, ${ }^{\mathrm{III}}$ a physiological $\mathrm{pH}$, is as a nondissociated species $\left(\mathrm{H}_{3} \mathrm{AsO}_{3}\right)$ with dipolar moment, it may be concluded that:

- The interaction of BSA with $\mathrm{iAs}^{\mathrm{V}}$ is the result of overcoming the ionized hydration shell of BSA, and the subsequent binding to amino acids is superficial, accessible, and charged. The result is an ionic bond.

- The interaction of BSA with iAs ${ }^{\mathrm{III}}$ is produced through the hydration shell in the hydrophobic regions of BSA (clathrate). The formed species increases the hydrophobic 
surface area. The rise of bound ligands would cause coagulation and precipitation of the BSA. The interaction is hydrophobic.

\section{Disclosure}

The authors report no conflicts of interest in this work.

\section{References}

1. Subhan N, Habibur R, Ashraful A, Rashedul I, Mahbubur R. Relationship between protein-binding and free drug concentrations of a sparingly water-soluble selective serotonin reuptake inhibitor (escitalopram) and its interaction with arsenic. Romanian J Biophys. 2011;21:139-149.

2. Tlustoš P, Száková J, Stárková A, Pavlíková D. A comparison of sequential extraction procedures for fractionation of arsenic, cadmium, lead, and zinc in soil. CEJC. 2005;3(4):830-851.

3. Dopp E, Hartmann LM, Florea AM, et al. Uptake of inorganic and organic derivatives of arsenic associated with induced cytotoxic and genotoxic effects in Chinese hamster ovary $(\mathrm{CHO})$ cells. Toxicol Appl Pharmacol. 2004;201:156-165.

4. Elmariah SB, Anolik R, Walters RF, Rosenman K, Pomeranz MK, Sanchez MR. Uptake of inorganic and organic derivatives of arsenic associated with induced cytotoxic and genotoxic effects in Chinese hamster ovary (CHO) cells. Dermatol Online J. 2008;14(10):24.

5. Caldwell KL, Jones RL, Verdon CP, Jeffery M, Jarrett JM, Caudill SP. Levels of urinary total and speciated arsenic in the US population: National Health and Nutrition Examination Survey. J Expo Sci Environ Epidemiol. 2008;1:1-10.

6. Hafeman DM, Ahsan H, Louis ED, Siddique AB, Slavkovich V, Cheng ZQ. Association between arsenic exposure and a measure of subclinical sensory neuropathy in Bangladesh. Occup Environ Med. 2005;47:778-784.

7. Gunduz O, Bakar C, Simsek C, et al. Statistical analysis of death causes (2005-2010) in villages with high arsenic levels in drinking water supplies of Simav Plain, Turkey. Arch Environ Occup Health. 2015;70(1): 35-46.

8. Chen Y, Graziano JH, Parvez F, et al. Arsenic exposure from drinking water and mortality from cardiovascular disease in Bangladesh: prospective cohort study. BMJ. 2011;342:1-11.

9. Webb JL. Enzyme and Metabolic Inhibitors. Vol III. New York, NY. Academic Press; 1966:595.

10. World Health Organization. Guidelines for Drinking-water Quality. 3rd ed. Geneva, Switzerland: World Health Organization; 2008:668pp.

11. Atlas Educativo de la República Argentina 2014. Available from: http:// www.mapaeducativo.edu.ar/images/stories/men/libro_hidroarsenicismo_completo.pdf.

12. Urbina NE, Sruoga P. La faja metalogenética de San Luis, Sierras Pampeanas: mineralización y geocronología en el contexto metalogenético regional. Rev Asoc Geol Argent. 2009;64(4):635-645.
13. Camean Fernández AM, Repetto Jiménez M. Toxicología Alimentaria (Chapter 18). España, Spain: Díaz de Santos; 2012:334-338. E-book.

14. Pizarro I, Román D, Solar C, Cámara C, Palacios MA, Gómez MM. Identificación y cuantificación del arsénico unido a las proteínas de tejidos cardiovasculares de pacientes sometidos a cirugía de revascularización coronaria. Rev Chil Cardiol. 2013;32:123-129.

15. Summers AO. Damage control: regulating defences against toxic metals and metalloids. Curr Opin Microbiol. 2009;12:138-144.

16. Lu M, Wang H, Li XF, Arnold LL, Cohen SM, Le XC. Binding of dimethylarsinous acid to cys-13alpha of rat hemoglobin is responsible for the retention of arsenic in rat blood. Chem Res Toxicol. 2007;20(1): 27-37.

17. Best CA, Laposata M, Proios VG, Szczepiorkowski ZM. Method to assess fatty acid ethyl ester binding to albumin. Alcohol Alcohol. 2006;41(3):240-246.

18. Bourdon E, Loreau N, Blache D. Glucose and free radicals impair the antioxidant properties of serum albumina. FASEB J. 2005;13:26-35.

19. Marino SM, Gladyshev VN. Analysis and functional prediction of reactive cysteine residues. J Biol Chem. 2012;287:4419-4425.

20. Stewart AJ, Blindauer CA, Berezenko S, Sleep D, Tooth D, Sadler PJ. Role of Tyr 84 in controlling the reactivity of Cys 34 of human albumin. FEBS J. 2005;272:353-362.

21. Trivedi MV, Laurence JS, Siahaan TJ. The role of thiols and disulfides in protein chemical and physical stability. Curr Protein Pept Sci. 2009;10:614-625.

22. Uddin R, Saffoon N, Ashraful A. Effect of arsenic on paracetamol binding to bovine serum albumin using site specific probes. Int Cur Pharm J. 2012;1:361-365.

23. Shen S, Li X-F, Cullen WR, Weinfeld M, Le XC. Arsenic binding to proteins. Chem Rev. 2013;113:7769-7792.

24. Brookins D. Eh-pH diagrams for geochemistry. In: Brookins DG. Science and Technology Letters. Berlin, Alemania: Springer-Verlag; 1988:91-100.

25. Klotz IM, Walter FM, Pivan RB. The binding of organic ion by proteins. JACS. 1946;68:1486-1490.

26. Ross PD, Subramanian S. Thermodynamics of protein association reactions: forces contributing to stability. Biochemistry. 1981;20: 3096-3102.

27. Russo D, Baglioni P, Peroni E, Teixeira J. Picosecond hydration water dynamics of a completely hydrophobic small peptide. Chem Phys. 2003;292:235-245.

28. Janin, J. Wet and dry interfaces: the role of solvent in protein-protein and protein-DNA recognition. Struct Fold Des. 1999;7:R277-R279.

29. Steinhardt J, Krijn J, Leidy JG. Differences between bovine and human serum albumins: binding isotherms, optical rotatory dispersion, viscosity, hydrogen ion titration, and fluorescence effects. Biochemistry. 19 71;10:4005-4015.

30. Curvale RA, Debattista NB, Pappano NB. Interaction between 2,4dihydroxychalcone and the N, F, E conformers of bovine serum albumin: influence of temperature and ionic strength. Protein J. 2012; $31: 293-299$.
Research and Reports in Biology

\section{Publish your work in this journal}

Research and Reports in Biology is an international, peer-reviewed, open access journal publishing original research, reports, editorials, reviews and commentaries on all areas of biology including animal biology, biochemical biology, cell biology, ecological studies, evolutionary biology, molecular biology, plant science and botany. The

\section{Dovepress}

manuscript management system is completely online and includes a very quick and fair peer-review system. Visit http://www.dovepress. com/testimonials.php to read real quotes from published authors. 